\title{
How Much Law Does the School System Need?
}

UDK: $34: 37$

\author{
Miro Cerar \\ University of Ljubliana, Faculty of Law \\ miro.cerar@pf.uni-li.si
}

\section{ABSTRACT}

In its ideal form, the law is a guardian of the freedom and autonomy of the school system. On the other hand, the school system must, as part of its responsibility, establish a respectful and responsible attitude toward the rule of law. In Slovenia, practice deviates from such ideal to too great an extent. Excessive and inappropriate legal regulation reduces the freedom and autonomy of the school system. The consequences within this system are: partly ignored legal regulations, and the resulting ineffectiveness; excessive legal administration in schools; increased teachers' opposition to the law; a lack of teachers' motivation; and, as a consequence, worsened quality of the educational process. The law, however, is only a part of the problem. The latter has its roots mainly in a general disorientation of society with regard to its values. In order to establish the right measure and manner of the legal regulation of the school system, the moral and common sense basis of society must first be healed and strengthened.

Keywords: freedom and autonomy of the school system, upbringing, education, autonomy of law, the criteria of law

JEL: K19

\section{The relative autonomy of law and the school system}

The field of law is so varied that, upon in-depth reflection, it is truly surprising that topics so very different are considered within this (collective) concept. For all fields the law regulates various criminal conduct (criminal offences, misdemeanours, disciplinary violations), civil delicts, the conclusion of a wide variety of contracts, the legal status of individuals and the many types of associations, organizations, and state authorities, administrative affairs, property ownership relations, employment 
relationships, social security, copyright, industrial property rights, marriage and family relations, inheritance, etc. On one hand, the constitution ensures human rights and establishes the foundations of the organizations of the state, while on the other, laws and implementing regulations broadly extend and complete all of this to the micro-level of normative dimensions. Legal acts regulate relationships related to birth and death, work, finance, banking, traffic, food, transportation, insurance, health care, veterinary medicine, media, informatization, spatial planning, construction, ecology, sport, waters, forests, agriculture, arms, chemicals, animals, animal feed, etc. - practically everything we do is to some extent regulated by legal acts.

The field of education, which is one of the more, or even the most, important fields of social life, also must be regulated by law. If the amount of time people in contemporary, modern society spend within the framework of institutionalized educational institutions is considered, as well as how our education and knowledge are co-conditioned by education in the broad sense of this term, the full relevance of the legal regulation of this field can be realized. Since the school system is a relatively autonomous area dealing with the upbringing and education of children ${ }^{1}$, in relation to it the law must have mainly regulative and incentive functions. This does not mean that in relation to the educational system the law does not also have (co-)defining ${ }^{2}$, repressive ${ }^{3}$, and other

1 Although it is possible to analytically deal with upbringing and education separately, the two are actually existentially inseparable phenomena. Whoever provides upbringing also provides education, and whoever provides education also provides upbringing. Regardless of the various possibilities of a separated or connected understanding of both of the mentioned processes of learning in a broader sense, I will proceed from the conviction that the fundamental mission of the school system is the education and upbringing of children and adolescents. In this text, at times only the word education is used, but it is intended to cover both terms.

2 By the (co)defining function of the law in relation to the school system, I refer to establishing the status and organization-related legal norms of the fundamental institutions of the school system (schools, teachers, pupils, the teaching and upbringing process, the rights and duties of subjects in the school system, etc.). In the realization of this function, the law must take into account many important essential and existential characteristics which the field of schooling determines according to its nature and the manner of its existence and functioning, by its internal, relatively autonomous actors and factors. Simply stated: in the process of determining and regulating the fundamental institutions of the school system, the law must throughout partially adapt to their form and content, while partially it defines the same form and content autonomously - this therefore entails a dynamic interaction between the fields of law and the school system. 
functions ${ }^{4}$, however in this relationship that part of the law must be the predominant which enables and encourages schools and teachers to uninterruptedly and successfully perform their fundamental mission related to education and upbringing.

At this point, two autonomies meet (or "collide"): that of the school and that of the law $w^{5}$. Both autonomies are only relative ${ }^{6}$. With regard to such, it is most important that the relationship between them is always based on dynamically establishing the right measure. However, in this case the right measure does not entail some general equality or symmetry, since in some areas of the school system the right measure requires more autonomous space for the school system, while in others more for the law.

3 By the repressive function, I refer to the compulsory aspect of law which is demonstrated by the obligatory nature of legal norms, and envisaged sanctions for the violation of such, and in the procedures for implementing sanctions or for actually enforcing the law.

4 In general, the law has regulative and repressive social roles and functions. In addition to this, among the fundamental functions of contemporary modern law, theory classifies above all also ensuring justice and the safety of legal subjects, ensuring order and peace, personal freedom, and the freedom of the private (ownership) sphere of individuals, social security, social cooperation (contractual, associative, etc.) and social integration (in terms of the system, the law has the role of an important social subsystem) (Coing, 1993, pp. 143, 145, and 156; Horn, 1996, pp. 22-26).

$5 \mathrm{In}$ a democratic state based on the rule of law, however, such a relation is certainly, in general, characteristic of all fields of the legal regulation of social relations, since just as the law preserves its own relative autonomy in relation to the fields it regulates (e.g. in relation to politics, the economy, religion, health care, the school system), also these fields preserve their relative autonomy in relation to the law.

6 On the factors of the relative autonomy of modern law (i.e. having a formalized, abstract, general, and systematic nature, the legal language, the professionalization of the roles of actors in the legal field), see Cerar, 2001, pp. 21-28; with regard to the autonomy of the school system, what should first be mentioned is the categorization of three types of autonomy: 1) complete autonomy entails that schools make decisions completely independently, but within the framework of legal and other general regulations, and possible external authorities do not interfere with any decisions; 2) partial autonomy entails that schools make decisions within the framework of possibilities determined in advance by a higher body of the school authority or they must obtain the consent of such higher body for their decision; 3) transferred autonomy appears when the authorities of the state administration or local authorities can decide, upon due consideration, whether to transfer the competency to make decisions in a certain field to schools (Šolska avtonomija $\checkmark$ Evropi, Politike in ukrepi, 2008, p. 17). It is necessary to add to this that all of the mentioned types of autonomy are only relative since even the most "complete" autonomy of the school system is limited in relation to other (autonomous) fields of society and by the fact that the organs of the authorities determine the organizational, financial, human resource, expert, and other aspects of the extent and content of school system autonomy by means of regulations. 
The legal regulation of the school system therefore must not only be very "rainbow-like", since different (sub)fields within the school system demand a differentiated approach, but also very varied in its (quantitative) scope. Some fields of activity of the school system by their nature can not bear a great amount of law (e.g. teaching), while others are necessarily directly conditioned by legal regulations (e.g. ensuring earthquake and fire protection in schools).

\section{Law as the guardian of the freedom and autonomy of the school system}

The school system and the law as codependent autonomous fields and social (sub)systems directly and indirectly interact with numerous other relatively autonomous social fields or (sub)systems (e.g. politics, culture, science, religion, the economy, finance), which greatly increase the complexity of the entire field within which the law and the school system are only two out of many partially overlapping fields. Just like many social (sub)systems are not able to successfully function without the school system, also the school system can not function without them, therefore it is important to be aware that the autonomous aspects of the law and the needs and requirements of the sphere of the school system for specific legal regulation are far from representative of the entire scope of the law that regulates the school system. Namely, the school system is always affected by legal acts which regulate the other above-mentioned relatively autonomous fields of social life?

In order to illustrate the above mentioned and as a starting point for further consideration, let us examine two situations. Firstly, if the law excessively intervenes into the autonomy of the school system, it thus hinders or prevents the professional freedom and autonomy ${ }^{8}$ of teachers and school management and thus worsens the quality of educational functioning. Secondly, if the school system is severely insufficiently regulated by norms, this leads to disorder, the abuse of power by

7 For example, regulations which regulate emploment relations, safety at work, fire safety, the protection of privacy, access to information of a public nature, financial operations, administrative procedures, traffic safety, environmental protection, etc.

$8 \mathrm{In}$ this article, by the term freedom I above all mean an intellectually and otherwise open and creative spirit in the schooling process of upbringing and education, and by the term autonomy, I above all mean the independent organization and functioning of the school system and educators within the frameworks determined by state or local law. 
the stronger to the detriment of the weaker participants in the schooling process, and last but not least, to unbalanced and low quality education. In these situations we usually talk about an "excessive" or "insufficient" amount of law, respectively. However, such a diagnosis demarcates only the most superficial manifestations of this "social disease", and not its deeper forces and even less so causes. This problem can also be perceived in other social fields, with regard to which we often talk about a hypertrophy of legal regulations, of their ineffectiveness, of double legal measures (e.g. different legal treatment of the representatives of higher and lower social classes), etc. Such thinking often leads to a critical consideration (or condemnation) of the law and lawyers.

However, the law and lawyers are here only part of the "big picture". Certainly, lawyers and the law have to be ascribed a great deal of responsibility for the flood of legal regulations and their effectiveness. Nevertheless, with regard to such, one has to be aware that the law is to a large degree only a conduit (or bearer) of value-related and other content created by other value- and norm-related spheres (habits, morals, ethics, customs, religion, politics, etc.). The law most frequently only conveys such content and transforms it into its formalized normative mechanism and expresses it in the specific form of laws, rules, judgements, contracts, and other legal acts.

Let me illustrate this. When in the formulation of a criminal offence the starting point of the law is the prevailing moral condemnation of, for example, taking someone else's property, the law creates the criminal law institute of theft, which it expresses in a formalized linguistic form, with regard to which theft as a criminal offence must be legally defined and implemented in a special legislative procedure, and its normative description must definitively and clearly contain all characteristics of this criminal offence and the envisaged sanction for such. If an article of the law on theft is unskilfully formulated, the lawyers who formulated it should be held responsible, as should the politicians if they adopted it in the legislative procedure without sufficient prior review. The core of the matter, however, i.e. the condemnation of theft, is in its commonsensical, moral, and ethical basis a matter of the entire society and not (just) of lawyers. As long as the society morally and commonsensically in principle 
largely condemns theft ${ }^{9}$, also the criminal law provision on theft will to a large degree be effective in practice. When, however, the moral awareness and commonsensical awareness of society become more strongly distorted, the law is also no longer able to effectively prevent theft. Since people are very imperfect, their moral, ethical, and other awareness, and consequentially societal practice, are always to some degree distorted or bent out of shape. When such a deviation exceeds some critical limit, which in Slovenia and elsewhere in the world has already happened in some areas (e.g. in the economy and politics), the hitherto value system starts to disintegrate and gradually its antipode begins to prevail. In such an insensitive environment in terms of values, great and damaging thefts perpetrated by the political, economic, and other social elites by means of various appropriating manipulations are no longer perceived as thefts, but merely as some kind of "higher necessity". After the social elite, by its own example, has imposed and allowed such a distortion of the value system long enough, and in this way of course grown richer and remained in power, the distortion is gradually transferred onto lower levels, i.e. social classes, where at first disorientation or apathy in terms of values appear, and afterwards a large share of the people start acting in accordance with the mentioned examples, which entails that a larger share of the people conveniently reevaluate their values, and bow to and join the thieves.

In recent years we have been facing a real flood of regulations which directly or indirectly regulate the field of the school system ${ }^{10}$ and restrict or even suffocate it as regards its fundamental mission by their extensiveness and content ${ }^{11}$. A large portion of such regulations is certainly necessary

9 Morals and the principles of common sense are expressed and co-formulated also through the dimensions of politics, religion, various professional ethics, etc.

10 Although in this field data on laws and implementing regulations is not systematically and clearly recorded, it is possible to ascertain, according to some informal evaluations of experts from the Ministry of School and Sport, that the number of laws that entirely or partly address the field of the school system is approximately 100, while the number of implementing regulations exceeds this number by at least one third.

11 Such is also the conclusion of the Working Group for Analysing the Legal Regulation of the School System, which has been active within the Slovenian Ministry of Education and Sport since January 2009. The Group is composed of experts from different disciplines, with the majority of its 11 members being lawyers. After one year of functioning the Group formulated a memorandum entitled "The Fundamental Conclusions of the Working Group", which is intended to be a general guideline for the further work of the Ministry and all institutions in the field of schooling. I will quote the memorandum in its entirety due to its relevance to the theme of this article: 
1. The legal regulation of the school system can be of assistance and can foster its high quality functioning only if it reflects a clear vision of the functioning and development of the whole sphere of the school system, above all primary and secondary schools, as well as music schools, preschools, and higher education. Such a vision, i.e. an implementation strategy, should be formulated as the fundamental prerequisite of the regulation of the school system by laws and implementing regulations on the basis of a broader expert and public debate, with regard to which the law (the Constitution, legislation) has to be taken into account throughout as one of its necessary accompanying frameworks already in the phase of the expert discussion regarding such a vision.

2. Legal regulations must to a greater degree enable the autonomy of the teaching process. In order for such, it is primarily necessary to allow and foster greater autonomy of principals and the professional autonomy of teachers by means of legal regulations and to the appropriate degree also expand all other aspects of the autonomy of the school system. Such an approach, however, should not lead to imbalance, therefore it is at the same time necessary to preserve the appropriate mechanisms for ensuring the responsibility and obligations of schools (principals, teachers) for their functioning and for the appropriate protection of the rights of children.

3. With regard to the legal regulation of the rights of children (pupils and students at all levels of schooling), it is necessary to appropriately regulate their duties (obligations).

4. The school system is overburdened by legal regulations. It is necessary to gradually eliminate those regulations which make impossible or hinder the quality functioning of the school system and its implementers. With regard to this, the levels of the necessary legal regulation must be determined, in the sense of the de/centralization of individual fields (i.e. mandatory content which must be treated in a uniform manner should remain a legal and rule-based matter in the domain of the Ministry, while everything else should be deregulated or at least left to the autonomous regulation of individual schools).

5. The above-mentioned conclusion regarding the school system being overburdened by legal regulations should not lead to activities which would in general decrease the importance of law for the regulation of the school system, since law is one of the fundamental mechanisms for ensuring appropriate conditions for the activities of the school system and respecting the rights and duties of all who participate in schooling processes. Moreover, upon the prior elimination of administrative burdens, the law should be understood as a necessary component of the functioning of the school system.

6. In the so-called umbrella regulations in the field of schooling, a greater mutual harmonization of some legal concepts and institutes must be ensured.

7. In the future, in (amended) school legislation all the most important and fundamental issues related to the rights and duties of children lpupils and students at all levels of schooling) must be regulated by laws and not by other, lower order legal acts, with regard to which uniform approaches on all levels of education should be followed (e.g. regarding grading, awards, disciplinary warnings and measures, work with children with special needs, food provided at school), if such is reasonable and there is not a need to apply different regulations to primary, secondary, or other schooling levels.

8. Where it is possible and beneficial, it is necessary to implement or foster by legal regulations a higher level of organizational uniformity of regulation in the broader

Uprava, letnik IX, 1/2011 109 
and inevitable since institutionalized education requires an appropriate legal order for its functioning. In this sense, a state based on the rule of $\mathrm{law}^{12}$ is an aid and an ally of the school system and its actors since it determines in advance the legal rules of the game and establishes the rights and obligations of the participants in educational processes and of the subjects which influence such processes "from outside". This can be well understood only if we look into the past and see how the absence of a state based on the rule of law inevitably led to the arbitrary conduct of the authorities, to the oppression of the majority by a minority, to legal inequality, to unpredictability, and last but not least, to the lack of freedom of individuals who are not recognized fundamental and other rights. However, also a state based on the rule of law, as an extremely important phenomenon of a law-based civilization ${ }^{13}$, must - just like everything else in human society - be of the right measure. In connection with such, in the mid $19^{\text {th }}$ century Friedrich Julius Stahl wrote very appropriately and in a balanced manner the following: $» A$ state must be a state based on the rule of law. That is a solution to and the truth of the developmental needs of the recent era. It should in a legal manner

field of schooling (e.g. the possibility of formulating the uniform fundamental principles of the "school order" within the segment of public services, i.e. for public institutes and concession holders).

9. Legal regulation must stimulate schools to modernize, that is, it must ensure conditions and initiatives for the continuous adaptation of teaching approaches to the new generations of children and adolescents and in accordance with new professional findings.

10. With regard to the regulation of resolving conflicts of interest which appear in the educational process, the legal regulation of the school system must, to the degree it is possible or allowable, simplify (administrative) legal procedures and above all place greater emphasis on and enable so-called alternative and consensual methods of resolving disputes. Where it is possible, also the obligatory uniform order of the entire administration has to be adapted to the peculiarities of the field of schooling.

12 For a state based on the rule of law, it is characteristic that its constitution, laws, and other formal legal sources implement the principles of equality before the law, legal certainty (the predictability and reliability of the law), and in this framework especially the predetermined legal violations and sanctions for such. In a state based on the rule of law, the rights and duties of legal subjects are determined by law, the most important of which are the fundamental (human) rights determined in the constitution. The laws precisely determine in advance the procedures by which the competent state authorities ascertain whether a legal violation has been committed and what sanction should follow. These and other fundamental elements of a state based on the rule of law are in theory and normative practice differentiated in further detail (Pavčnik, 2009, pp. 32 et seq.).

13 For more on this, see Simič, 2009, pp. 13-26.

110 Uprava, letnik IX, 1/2011 
precisely determine the directions and limits of functioning, as well as the area of the freedom of its citizens. This it should fully protect. With regard to such, however, due to the moral ideas of the state, it should not implement (force) such beyond the limits of the territory of the law. This is the concept of the state based on the rule of law. "14

In the correctly understood concept of the state based on the rule of law, an essential and very important element is the freedom of citizens and individuals. It was Kant who characterized the Age of the Enlightenment and with it the new rationally "enlightened" law with his famous, although only formal definition of law, according to which law is a conglomerate of conditions under which the free will of an individual can, according to some general law of freedom, associate with the free will of another individual. ${ }^{15}$ Also from the perspective of the contemporary establishment of the state based on the rule of law, it must be mentioned that such does not exist without the sufficient freedom of individuals and all those spheres of society which inevitably need enough free space for their existence, functioning, and development. ${ }^{16}$ Since the school system without a doubt is part of such a social sphere, it is especially inappropriate for it to be burdened by the law to an excessive extent and with the wrong emphasis. If we apply the idea of the above-quoted Stahl, we can say that especially in the field of the system of schooling, the state must not overstep the limits of the sphere of law. ${ }^{17}$ Since relative freedom is a necessary component of any human and social autonomy, also the autonomy of the school system, the latter system can appropriately function only if the law provides it enough freedom with regard to teaching and also other professional and organizational functioning. Otherwise, the school system can not carry out its fundamental mission in a comprehensive and successful manner since it can not educate children and adolescents so that they are sufficiently mentally (intellectually) free and autonomous individuals in terms of their personality.

If at this point we briefly address the concept of freedom in a broader social context, we can see that the modern democratic state is/was

14 Cited after Simič, ibid., p. 13.

15 Kant, 1967, p. 32.

16 Naturally, at this point the ever present problem of how to understand the concept of freedom arises, which we will discuss below.

17 Below (Sect. 3) I will concisely address the criteria of law which generally determine or limit the field of law. 
founded on political liberalism and the doctrine and practice of the socalled classic (liberal) human rights, which all largely stem from the concept of so-called negative freedom (the so-called "freedom from interference"). This form of freedom is concisely expressed in the demand for "the right of an individual to be left alone". Along side this, democratic society has also established a positive concept of freedom, the so-called "freedom to" 18 , which is demonstrated primarily in an individual's fundamental rights as a citizen, i.e. political rights, thus in his legally protected possibility to participate in public affairs. For the positive development of an individual in terms of values, a comprehensive and dynamic balance between both forms of freedom is necessary, which thus gradually grows into an integral concept of freedom, encompassing all of its negative and positive aspects. On the societal level, these imply the individual's awareness of necessary self-limitations for the benefit of the freedom of others. The freedom (and rights) of everyone in a democratic society and a state based on the rule of law are namely limited by the same freedom (and rights) of others, which entails that a free individual must be aware not only of his own entitlements, but also of his duties to others and to society. In addition to this, it is important to be aware that raising awareness of these and other aspects of freedom and of the possibilities and manners of its actualization is primarily ensured by means of appropriate upbringing and education (at home, at school, and elsewhere), and of course also by means of institutional measures, among which the law plays a crucial role.

Two important conclusions follow from the above mentioned. Firstly, an integral concept of freedom implies both entitlement and obligation (responsibility). This entails that we can help a child or adolescent grow into a free and autonomous personality in terms of thinking and otherwise only if we constantly remind them of the necessity of balancing rights and duties. A young person has to be brought up and educated in a spirit of personal responsibility, which on one hand demands knowing and

18 Among the first thinkers who tried to explain the distinction between negative and positive freedom was the French liberal thinker Benjamin Constant, who at the beginning of the $19^{\text {th }}$ Century wrote that the ideal of the Liberty of the Ancients was participation in the state authority (positive freedom) and the ideal of the Liberty of the Moderns is a state of liberation from the state authority (negative freedom). In ancient times individuals were emancipated primarily through their participation in public (state) affairs, while in the modern age they are emancipated primarily through independence as regards their private life (see Tadić, 1988, p. 18 et seq.).

112 Uprava, letnik IX, 1/2011 
fulfilling one's moral, ethical, and legal duties, and on the other, knowing one's fundamental (human) and other rights and appropriate legal procedures for their realization.

Secondly, the school system, which itself is not (sufficiently) independent, since it is excessively trapped in a vice of unnecessary bureaucracy, can not create enough independent spirit for truly high quality learning. Such a school system constantly conveys the message to young generations, during and along side the teaching process, that life primarily entails dealing with records, legal means, procedures, decisions, etc., and that it is very "dangerous" 19 to live outside the legaladministrative framework. Such influence is often transferred onto students, teachers, parents, and others subconsciously, since they are not able to constantly consciously reflect upon such bureaucracy. Consequently, a large share of such excessive "legal-administrative mentality" ${ }^{\prime 2}$ is expressed with regard to (adult) citizens in terms of their everyday lives, since they often feel "lost" or do "not find their way" in situations for which some legal act does not clearly define how they are allowed or not allowed to act. In addition to this, in the event of a dispute or problem (if, for a moment, I may focus on this aspect) they already primarily focus on the legal dimensions of its resolution, without first investing their energies and efforts in attempting to reconcile or to find the middle ground on the basis of customary, moral, ethical, and similar extra-legal approaches. Having said that, I do not wish to diminish the great importance of law for modern society. However, also in a state based on the rule of law, the law as a means of resolving conflicts must be the last instance, an emergency exit, since if in this respect we ascribe

19 Although as a father, citizen, and lawyer I firmly support safe schools, which also implies ensuring safety with regard to various sport days, field trips, school excursions, nature schools, etc., I am opposed to the hysteria which - largely following the American (USA) example - is now gradually being implemented also in Slovenia. I am referring to different kinds of forms to be filled out whose aim is to catalogue in great detail all possible sorts of dangers and accidents, and to protect children from them, which excessively frighten parents and teachers and often demotivate the latter with regard to them voluntarily and happily deciding to participate in such trips and activities. Also here we are losing the right measure.

20 I should again emphasize that criticism here is directed only at exaggerated faith in the law and in its use. The right measure of the law and appropriate administration is of course necessary and beneficial for the school system as well as liberating, as it ensures the autonomy and appropriate freedom of teaching. 
the law too great an importance, we also weaken the state based on the rule of law and democracy themselves. ${ }^{21}$

If due to excessive and incorrect legal regulation the school system is no longer sufficiently independent in its educational mission as well as with regard to some other professional and organizational aspects, it then transfers such non-freedom to all those participating in the process of schooling. In the event of such, the school system does not educate free minds, but people that are generally replicas of some sort of schooling plans, programmes, forms, etc., which a society which wishes to be democratic, creative, and comprehensively successful should by no means wish for. In addition to this, as has been explained above, it is necessary to be aware that excessive or inappropriate legal regulation is to a large degree a reflection of the general disorientation of society on moral, ethical, and commonsensical levels, and only to a limited degree is it also a reflection of specific and relatively autonomous legal factors (the influence of the judicial system, the activities of all kinds of professional lawyers, etc.). Therefore, it is in the school system itself where an important step in the transformation of the value-based mentality must be taken, by dedicating more educational time to moral-ethical topics and to the treatment of the emotional sphere, and at the same time also by teaching how to create and maintain a respectful and correct attitude to the law and how important the balance between one's own duties (responsibilities) and rights is. At the same time, the school system must be ensured more educational and other autonomy by constant improvements in the legal regulation and by a certain degree of state-based legal deregulation. In such a manner, the law must gradually achieve the right measure in the field of the school system and thus more appropriately realize its fundamental role, i.e. as the guardian of the freedom and autonomy of the school system.

\section{The criteria of law and the legal regulation of the school system}

The criteria of law tell us what the characteristics of the law are and what can be regulated appropriately by the law. They help us define what

21 See Cerar, 2009, especially pp. 94-96.

114 Uprava, letnik IX, 1/2011 
Stahl (see above) has named the sphere of the law. The fundamental criteria of law are primarily the following: ${ }^{22}$

a) Normativeness. Law is a normative phenomenon, it is ought-ness (Ger. Sollen), and does not follow the laws of causality, such as are known in the technical and natural sciences.

b) Effectiveness. It is only sensible to talk about the law as long as the system of legal norms as a whole is predominantly socially effective, which means that it is to a predominant or relevant degree realized in social practice. Otherwise, legal norms remain mere words on paper and can not be ascribed the status of the real, i.e. functioning, law.

c) Conflictual nature. Legal norms regulate those social relationships which are potentially or actually conflictual. One of the fundamental tasks of law is thus to prevent or eliminate (already occurring) interpersonal and social conflicts. This concerns not only the fact that in this manner the law prevents disputes between people which can lead to psychological or physical violence, and by such it acts preventively to ensure relative social peace, but it also entails that the task of the law is to ensure appropriate legal certainty (the predictability and reliability of the law) and with such, social order. Successful realization of the principle of legal certainty establishes among citizens trust in the law, which might even be the most important legal good, since just like trust is in general a cornerstone of interpersonal relations, trust in the law is the cornerstone of a state based on the rule of law.

d) Possibility and necessity of legal regulation. All social relations, also those potentially or actually conflictual, are certainly not of such a nature that they should be regulated by law. Firstly, legal norms can regulate only such phenomena or the desired conduct and behaviour of people that the institutions of authority can control and direct to a sufficient (relevant) degree. This means that, e.g. such legal norms would not be reasonable which would require that teachers must ensure that every student knows all of the taught material perfectly or that every individual must only think well of others. In legal practice it would be impossible

22 Here I provide only a brief description of these measures. For more on this, see Cerar, 2006, pp. 41-48. 
to sufficiently realize such rules or to control the course of their realization. Secondly, legal norms must regulate only those social relations for which the interference of the law is necessary. If a certain interpersonal relation is conflictual, this does not entail that it must necessarily be regulated by law. For example, breaking promises, forgetfulness, or excessive loquaciousness when in the company of other people can cause tension or conflicts between individuals, but this is not always a reason to regulate and punish such actions by law. Often in such situations moral and customary norms and the sanctions arising therefrom are sufficient. However, when, e.g. a broken promise causes an individual great material or psychological injury or when excessive loquaciousness leads to insulting a person, then the level of conflict is often no longer entirely manageable by resorting to only moral and customary means. Therefore, in the event of such, the law steps in - at least as an additional mechanism for preventing or settling the conflict. The criteria of the possibility and necessity of legal regulation are of course in close relation to the above-mentioned criterion of the effectiveness of the law.

e) Orientation towards the external behaviour of individuals. Legal norms largely regulate the external behaviour and conduct and relations of individuals. Only in exception must the law interfere with the internal world of the individual, when this is indispensable for its legitimacy and effectiveness. For example, in establishing the legal responsibility of an individual, as a general rule it is necessary to determine his true contractual will (not only his will expressed in the written contract), guilt (e.g. the intention to perpetrate a criminal act), sanity, etc.

f) Compulsion and (state) sanctions. Legal norms are of a compulsory nature, which also entails that in the final instance their realization is ensured by the state by means of compulsory measures carried out by state authorities competent for such (e.g. the police, inspectorates, state prosecutors, courts). However, the compulsory nature of legal norms does not necessarily entail that legal addressees actually perceive each individual legal principle or regulation as compulsory. In the event legal norms are morally, generally, and otherwise acceptable to the majority of citizens (e.g. the prohibition of murder), such norms are mostly 
automatically or spontaneously respected by legal addressees, which is why they are compulsory as a general rule only for those individuals who violate them. On the other hand, the law also contains a great number of such legal norms which the legal addressees thereof to a large degree do not approve of morally or internally (e.g. some tax requirements), but they do, due to the compulsory nature of such norms, mostly act in accordance with them.

g) Values. If values are not taken into account, the law would be, in accordance with all the hitherto mentioned criteria of law, a mere form, which it would be possible to fill in with any selected content (matter). The law as a system of legal norms is therefore imbued with values such as social peace, order, justice, legality, and freedom. This is immediately evident with regard to some legal norms (e.g. the prohibition of torture or allowing free political and other kinds of association) since in the event of such, moral, customary, political, and other values are at issue, which are more or less generally well anchored in the social consciousness. At the other extreme there also exist legal rules which are in themselves seemingly neutral or indifferent with regard to values (e.g. determining a deadline for filing an appeal or the rule that a red light means "stop"). However, also in such cases it is certainly possible to perceive the presence of certain values when such "legal-technical" rules are related to their value-based starting point. Determining a deadline for filing an appeal, for example, on one hand protects the possibility of an individual to object to a decision of a state authority which he or she does not agree with (this concerns the protection of the personal integrity of the individual and his or her right to express criticism) and on the other hand establishes the necessary order in legal procedures, which cannot last forever. This alerts us to the fact that the law is an integral whole imbued with values in which individual values are differentiated with various intensities according to their individual parts.

If we take as our starting point the listed criteria of law, we can determine that the legal regulation of the school system in Slovenia in many aspects neglects their message and significance. For example, a considerable portion of the regulations regarding the school system 
do not sufficiently take into account the criteria of the possibility and necessity of legal regulation. This entails that legal regulations regulate too many issues or regulate them in an excessively complicated manner, which is why, to some extent, school authorities and teachers simply do not implement them in practice ${ }^{23}$, since if they did so they would not manage to carry out their basic work (which is, to a large degree, also determined by regulations ${ }^{24}$ ).

Furthermore, what is often overlooked is the real significance and message of the criterion of the conflictual nature of the law. Instead of the legislature regulating by laws and implementing regulations only those relations in the field of the school system that are already causing conflicts or really could cause such, legal acts often regulate relations which have been, up to that point, largely non-conflictual and which also do not demonstrate serious signs of potential conflict. Thus, excessive or only seeming concern for children's rights ${ }^{25}$ or for the transparency of the work of schools often leads to the artificial establishment of new legal requirements and relations ${ }^{26}$, which needlessly creates an opportunity for the occurrence of conflictual situations which otherwise would not even arise ${ }^{27}$, or would only occur to a negligible degree and be resolvable by means of extra-legal mechanisms.

The field of values represents a special issue. How can legal values be harmonized with those values that are of key importance for the school system? If we connect this question to the above listed criteria regarding the possibility and the necessity of legal regulation and its conflictual nature, this brings us back to the already presented conclusion that in this respect a broader values-related problem is at issue, within which the law

23 For example, schools often ignore those provisions in laws which require, in certain cases, one to act in accordance with the law on administrative procedures. Since complaints and disputes most often do not arise in connection with such, this unlawful practice remains largely unnoticed.

24 In such a manner, a vicious circle appears, which educators often call attention to. The regulations are simply too extensive for schools to be able to entirely follow them and at the same perform high quality educational work.

25 Of course, it is necessary to be aware that children's rights are a special treasure, which the law must appropriately protect in all important segments (for more on this topic, see Novak, 2004).

$\mathbf{2 6}$ This is then followed by assigning new competencies to inspectorates or by establishing another authority, new legal procedures, sanctions, etc.

27 This is a situation reminiscent of a so-called self-fulfilling prophecy.

118 Uprava, letnik IX, 1/2011 
is only "partially to blame" for the decrease in the autonomy of the school system. With regard to this, the law to a large degree only reflects general social morals and mentality, which entails that it is only some kind of an "executive measure" of politics as the supreme concentration of such morals and mentality. If politics kept the law within the limits of its sphere, i.e. within the framework of the criteria of law, then legal values such as legal certainty, justice, legality, and freedom, would have a positive effect on the school system since they would enter into it only to such a degree and in such a manner that the necessary and beneficial frameworks for upbringing and educational processes would be established. However, due to the fact that in (our) society, which is confused in terms of values, the elites who establish and direct the organization and functioning of the school system, actually do not eliminate the confusion but practically ignore or even generate $\mathrm{it}^{\mathbf{2 8}}$, the legal regulation of the school system is inappropriate and consequently subdued or open conflicts arise between the representatives of the sphere of schooling and the performers of activities in the legal sphere (i.e. politicians, lawyers, bureaucrats, etc.), who have an extremely legalistic and apologetic stance towards legal regulations. This only contributes to the further growth of the well-known schism between the school system and the law, due to which educators often perceive the law as an unwelcome incursion into their own sphere, while lawyers (more precisely: performers of activities in the legal sphere) often underestimate the particularities of the field of schooling and are incorrectly of the opinion that it is possible to be active in the field of schooling merely on the basis of having a general knowledge of law (but with no specialist knowledge of the field of education). ${ }^{29}$

\section{Concluding thoughts}

The law and the school system are inevitably co-dependent. ${ }^{30}$ The law is, in its ideal construction or form, a guardian of the freedom and autonomy of the school system, while the school system must, as part of its responsibility, adopt a respectful and responsible attitude towards

28 Of course, also honourable exceptions exist.

29 Heubert 1999, p. 7

30 Cf. Hehir \& Gamm, 1999, pp. 205-239, who (in relation to the upbringing and education of children with special needs) call attention to the necessity of dedicated cooperation between the sphere of schooling and the legal-administrative sphere, with regard to which the authors suggest that further improvements in the system can be found in the concept they refer to as the "collaborative model of education reform". 
the state as a state based on the rule of law. Sadly, practice in Slovenia deviates too much from such an ideal. Excessive and inappropriate legal regulation of the school system decreases the freedom and autonomy of such, which is reflected in partial neglect of the regulations in the sphere of the school system and consequently as the ineffectiveness of such regulations, as the increased aversion of educators to law, as excessive legal bureaucracy at the expense of teaching and other activities that are more important and beneficial to children, as a lack of motivation to educate on the part of teachers, and thus a lower quality educational process.

The school system needs the right measure of law, which can not be defined empirically or numerically. In order to ascertain the actual situation, a true dialogue and relationship based on trust must be established between educators, on one hand, and the performers of activities in the legal sphere, on the other. Both sides must listen to each other and establish responsible cooperation. The law must, as much as possible, adapt to the requirements of such an autonomous school system which will raise and educate young generations to be as independent in spirit (creative and having a love of knowledge) as possible and at the same time socially responsible persons, while the school system must, of course, fully follow the basic principles of a state based on the rule of law, which also demands that the school system respect human and other legal rights and follow the principles of non-discrimination, legal equality, legal certainty, justice, proportionality, and legality.

The mentioned dialogue and (further) building of mutual trust between the representatives of the sphere of the school system and those of the legal sphere must be approached with patience and farsighted vision. One must be aware throughout that in the law as well as in the school system the starting point and the final objective of our (common) efforts are always human beings. It would be naive to place the "blame" for the decrease in the autonomy of the school system on law as such or just on lawyers, who are in this respect only a part of the whole story. It is necessary to look at the value system of the society, which, due to the inappropriate functioning of the social elites and the lesser or greater (but in general, excessive) passivity and apathy of the citizens, undergoes a gradual deconstruction. In such a situation, which leads to a general disorientation in terms of values and consequently to damaging social phenomena (e.g. excessive materialism and individualism, demonstrating 
a lack of respect or appreciation, consumerism, excessive competitiveness, lack of empathy, etc.), it is necessary, generally and especially in schools, to keep reminding people about and reinforcing the fundamental moral and commonsensical principles and practices. It is only in such a manner that in the future the performers of activities in the legal sphere will also be emotionally and intellectually mature enough to establish and dynamically maintain the right measure of law. Of course, this is only an ideal which we can never come close enough to. However, it must lead us away from those contemporary trends which have distorted this ideal and have blurred it to such a degree that, due to its increased unrecognizability, the law can, in the long run, turn into a mere and hypertrophied normative technique, and the school system into a robotized activity, which gradually but persistently deadens the human spirit.

Miro Cerar, Ph.D. is professor at the Law School of the University of Ljubliana, where he teaches Theory and Philosophy of Law and Comparative Law. In 1991-1992 he worked as Secretary of the Constitutional Commission that prepared the basic independence acts and the draft of the new Constitution of the Republic of Slovenia (1991). Since then he has been a permanent external consultant on constitutional matters to the Slovene parliament. In spring semester 2008 he was a visiting Fulbright professor at the Golden Gate University School of Law, San Francisco, where he lectured on Comparative Constitutional Law. Since December 2010 he has been the President of the Judicial Council of the Republic of Slovenia. 


\section{References}

- Cerar, M. (2009). (Ne)ideološkost pravne države [The (Non-)Ideological Nature of the State Based on the Rule of Law]. V: Cerar, M., Igličar, A., Kerševan, E., Pavčnik, M., Simič, V., Škrk, M., Testen, F., Wedam-Lukić, S. Pravna država [The State Based on the Rule of Law]. Ljubljana: GV Založba.

- Cerar, M. (2006). Splošni vidiki prava in pravne ureditve [General Aspects of the Law and Legal Regulation]. V: Bohinc, R., Cerar. M., Rajgeli, B. Temelii prava in pravne ureditve (za nepravnike) [The Foundations of Law and Legal Regulation (for Non-Lawyers)]. Ljubliana: GV Založba.

- Coing, H. (1993). Grundzüge der Rechtsphilosophie. Berlin - New York: Walter de Gruyter.

- Hehir T. \& Gamm S. (1999). From Legalism to Collaboration. Law and School Reform. Yale University.

- Heubert, Jay P. (1999). Six Law-Driven School Reforms: Developments, Lessons, and Prospects. Law and School Reform. Yale University.

- Horn, N. (1996). Einführung in die Rechtswissenschaft und Rechtsphilosophie. Heidelberg: C.F. Müller Verlag.

- Kant, I. (1967). Metafizika ćudoređa. Sarajevo: Izdavačko preduzeće "Veselin Masleša".

- Novak, B. (2004). Šola in otrokove pravice [School and Children's Rights]. Ljubliana: Pravna fakulteta, Cankarjeva založba.

- Pavčnik, M. (2009) Narava pravne države in njene prvine [The Nature of the State Based on the Rule of Law and its Elements]. V: Cerar, M., Igličar, A., Kerševan, E., Parčnik, M., Simič, V., Škrk, M., Testen, F., Wedam-Lukić, S. Pravna država [The State Based on the Rule of Law]. Ljubliana: GV Založba.

- Simič, V. (2009). Vladavina prava kot pravnocivilizacijski pojav [The Rule of Law as a Phenomenon of Law and Civilization]. V: Cerar, M., Igličar, A., Kerševan, E., Pavčnik, M., Simič, V., Škrk, M., Testen, F., Wedam-Lukić, S. Pravna država [The State Based on the Rule of Law]. Ljubliana: GV Založba.

- Šolska avtonomija v Evropi, Politike in ukrepi [The Autonomy of Schools in Europe, Policies and Measures]. (2008). Ljubliana: Eurydice, Informacijsko omrežje o izobraževanju v Evropi.

- Tadić, L. (1988). Nauka o politici. Beograd: Biblioteka Rad. 